\title{
ACCOUNTING BASED COVENANT PADA OBLIGASI PERUSAHAAN FINANCE YANG TERDAFTAR DI BURSA EFEK INDONESIA
}

\author{
Dwi Sulistiani \\ UIN Maulana Malik Ibrahim Malang \\ dwisulistiani@pips.uin-malang.ac.id
}

\begin{abstract}
ABSTRAK
Penelitian ini bertujuan menguji pengaruh jangka waktu obligasi, jaminan, profitabilitas, dan kualitas obligasi terhadap accounting based covenantTeknik analisis yang digunakan adalah logistic regression. Estimasi parameter untuk model logit di sini menggunakan prosedur estimasi nonlinier (nonlinear estimating procedure) dengan metode Maximum Likelihood Estimation. Hasil penelitian ini menunjukan bahwa kualitas obligasi berpengaruh pada pembentukan covenant pada perusahaan finance. Hal tersebut memberikan bukti secara empiris bahwa rating obligasi yang menunjukkan kualitas obligasi yang diterbitkan perusahaan finance cukup mengindikasikan keamanan suatu obligasi dan dianggap lebih bisa menjamin kemampuan perusahaan dalam memenuhi kewajibannya, sehingga dijadikan dasar dalam keputusan pembentukan covenant dalam suatu kontrak utang publik
\end{abstract}

Kata Kunci : kontrak utang publik; jangka waktu obligasi; jaminan; profitabilitas; kualitas obligasi dan accounting based covenant

\section{ABSTRACT}

This study aims to examine the effect of the bond period, collateral, profitability, and bond quality on accounting based covenants. The analysis technique used is logistic regression. The parameter estimation for the logit model here uses a nonlinear estimating procedure using the Maximum Likelihood Estimation method. The results of this study indicate that the quality of bonds influences the formation of covenants in finance companies. This provides empirical evidence that the bond rating that shows the quality of bonds issued by finance companies is enough to indicate the security of a bond and is considered more able to guarantee the company's ability to fulfill its obligations, making it a basis for decisions on covenant formation in a public debt contract

Keywords: public debt contract; bond period; guarantee; profitability; bond quality and accounting based covenant

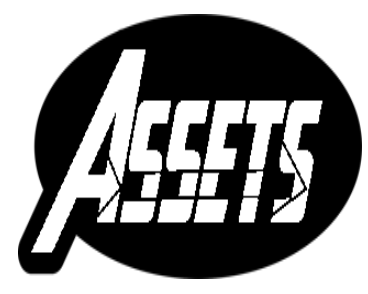

ASSETS

Jurnal Akuntansi dan Pendidikan

Vol. 7 No. 2

Hlmn. 120-128

Madiun, Oktober 2017

p-ISSN: 2302-6251

e-ISSN: 2477-4995

Artikel masuk:

12 Juli 2018

Tanggal diterima: 31 Oktober 2018 


\section{PENDAHULUAN}

Berdasarkan statistik pasar modal yang dikeluarkan oleh OJK (Otoritas jasa Keuangan) pada tahun 2014 grafik emisi efek menunjukkan 37,5\% terdiri dari obligasi dan sisanya berupa saham. Mulai tahun 2007 terus terjadi peningkatan untuk total nilai obligasi yang diterbitkan di pasar modal Indonesia, pada tahun 2014 tercatat 355,48 Trilyun Rupiah dimana 0,92 Trilyun Rupiah diantara berupa sukuk. Peningkatan tersebut membuktikan bahwa obligasi dan obligasi syariah (sukuk) masih banyak diminati oleh pasar, oleh karena itu penting bagi perusahaan untuk mempertimbangkan penerbitan obligasi demi memenuhi kekurangan modal yang dibutuhkan.

Berdasarkan data diatas menunjukkan bahwa obligasi masih diminati baik oleh manajemen perusahaan maupun investor. Obligasi merupakan salah satu jenis utang yang melibatkan pihak ketiga dalam suatu hubungan antara principal dan agent. Salah satu cara untuk memperkecil biaya pengawasan yang ditanggung oleh pemegang saham adalah dengan melibatkan pihak ketiga dalam pengawasan tersebut. Keterlibatan pihak luar akan mempersempit ruang gerak manajer untuk melakukan tindakan-tindakan dan mengambil keputusan yang menguntungkan dirinya sendiri, salah satunya dengan adanya perjanjian utang (covenant) dalam suatu kontrak utang (Jensen \& Meckling, 1976)

Ada beberapa hal yang harus dipertimbangkan dalam penentuan covenant apakah akan berbasis akuntansi ataukah berbasis jaminan, diantaranya adalah: materialitas, jangka waktu, jaminan, ukuran perusahaan, profitabilitas, pertumbuhan perusahaan, leverage, spread, reputasi, dan kualitas (Mu, Phelps and Stotsky, 2013; Reisel, 2014; Mariano dan Tribo, 2009; Inamura, 2009; Sulistiani, Subroto \& Chandrarin, 2014). Terdapat 2 macam covenant yaitu: covenant berbasis akuntansi (accounting based covenant) dan covenant berbasis jaminan (collateral based covenant). Dibandingkan dengan collateral based covenant, accounting based covenant memiliki pengaruh lebih besar terhadap aktivitas perusahaan dengan cara secara langsung membatasi angkaangka akuntansi. Alasan tersebut memotivasi peneliti untuk lebih fokus pada bagaimana accounting based covenant dibuat (Innamura, 2009)

Reisel (2014) menemukan bahwa reputasi perusahaan tidak mempengaruhi covenant pada periode pertama dan berpengaruh negatif pada dua periode terakhir, selain itu juga ditemukan bahwa kualitas akuntansi tidak berpengaruh pada covenant. Mariano dan Tribo (2009) menemukan bahwa perusahaan yang berkualitas, growth opportunities perusahaan, dan perjanjian kredit yang kuat mempengaruhi pembentukan covenant.

$\mathrm{Mu}$, et.al. (2013) menemukan bahwa pinjaman mulai setelah pernyatan ulang keuangan memiliki suku bunga lebih tinggi, jatuh tempo yang lebih pendek, kemungkinkan diamankan lebih tinggi dan batasan covenant yang lebih banyak dibandingkan dengan pinjaman yang mulai sebelum pernyataan keuangan. Sebagai tambahan $\mathrm{Mu}$, et.al. (2013) menemukan bahwa keuntungan perusahaan, growth opportunities, leverage, loan maturity dan materialitas pinjaman terkait dengan pembuatan covenant.

Inamura (2009) menemukan bahwa bond maturity, firm size, bond manager, leverage ratio, spread berpengaruh dalam pembentukan covenant. Penelitian tersebut menunjukkan bahwa jatuh tempo obligasi (bond maturity) yang panjang dan ukuran perusahaan issuer yang besar, seringkali berarti bahwa pemegang obligasi kurang mungkin untuk memasukkan accounting based convenant dalam kontrak utang mereka. Ketika terdapat bond manager dan rasio leverage dari issuer yang tinggi, pemegang obligasi seringkali memasukkan accounting based covenant ke dalam kontrak utang 
mereka. Inamura (2009) juga menemukan pengaruh alternatif antara pembuatan accounting based covenant dan suku bunga setelah mengontrol pengaruh simultan antara mereka. Ini berarti bahwa pemegang obligasi menetapkan accounting based covenant atau suku bunga untuk melindungi diri mereka.

Sudah banyak penelitian mengenai accounting based covenant yang dilakukan di luar negeri, diantaranya Mu, Phelps and Stotsky, 2013; Reisel, 2014; Chaudari ${ }_{23}$ aje and Singh, 2014; Mariano dan Tribo, 2009 serta Inamura, 2009 tapi untuk di ${ }^{23}$ lonesia penelitian mengenai hal ini baru dilakukan oleh Sulistiani, Subroto dan Chandrarin (2014). Hasil penelitian ini menunjukkan bahwa terdapat perbedaan hasil antara sampel keseluruhan obligasi dengan sampel yang dibedakan antara obligasi perusahaan finance dan non finance. Pada sampel keseluruhan obligasi accounting based covenant hanya ditentukan oleh nilai jaminan saja. Pada sampel obligasi perusahaan finance terdapat 4 faktor yang menentukan pembentukan accounting based covenant yaitu: jangka waktu obligasi, jaminan, profitabilitas, dan kualitas obligasi, sedangkan pada sampel obligasi perusahaan non finance ada 2 faktor yang menentukan pembentukan accounting based covenant yaitu: jangka waktu obligasi dan agunan/jaminan.

Penelitian ini meneruskan penelitian Sulistiani, et.al. (2014) yang dilakukan di Indonesia. Penelitian ini bertujuan menguji kekonsistenan hasil penelitian tersebut dengan meneliti perusahaan yang terdaftar di BEI tahun 2010-2014 yang merupakan periode lanjutan dari penelitian diatas. Penelitian tersebut menarik untuk dilanjutkan selain karena penelitian ini masih belum banyak yang meneliti di Indonesia juga karena obligasi merupakan surat berharga yang cukup besar diperdagangkan di pasa modal Indonesia sehingga penting untuk mengetahui apa yang mempengaruhi penerbitannya khususnya untuk obligasi yang berdasar pada angka-anggak akuntansi (accounting based covenant). Perbedaan dengan penelitian sebelumnya adalah bahwa penelitian ini objek penelitian difokuskan hanya pada perusahaan yang bergerak di bidang keuangan (finance) juga hipotesis menggunakan arah apakah positif ataukah negatif, selain itu pada penelitian ini tidak menggunakan variabel kontrol seperti penelitian sebelumnya karena lebih fokus pada perusahaan finance saja, dan level signifikansi sama pada tiap variabel yaitu 5\%. Tujuan yang ingin dicapai dalam penelitian ini adalah untuk menguji pengaruh (1) jangka waktu obligasi; (2) jaminan/agunan; (3) profitabilitas perusahaan; dan (4) kualitas obligasi terhadap pembentukan accounting based covenant.

\section{METODE PENELITIAN}

Penelitian ini tergolong dalam penelitian kuantitatif. Populasi yang digunakan dalam penelitian ini adalah seluruh perjanjian hutang (covenant) yang diterbitkan oleh perusahaan yang terdaftar di Bursa Efek Indonesia dan masih beredar per 31 Desember 2014. Sampel yang digunakan dalam penelitian ini adalah obligasi yang diterbitkan oleh perusahaan bergerak di bidang keuangan (finance) yang terdaftar di Bursa Efek Indonesia pada tahun 2009-2014.

Sampel dalam penelitian ini dipilih dengan metode purposive sampling karena peneliti ingin meneliti semua obligasi yang masuk dalam kriteria yang telah ditetapkan sehingga mendapatkan sampel sejumlah 96 obligasi. Sampel dipilih dengan kriteria sebagai berikut: perusahaan publik yang menerbitkan obligasi telah terdaftar di Bursa Efek Indonesia berdasarkan situs resmi BEI (www.idx.co.id) mulai tahun 2008, diterbitkan pada periode 2010-2014, Data obligasi dan laporan keuangan tersaji lengkap mulai 2 tahun sebelum periode penelitian, bukan merupakan obligasi syariah 
(sukuk ijarah), bukan merupakan obligasi subordinasi, memiliki suku bunga tetap dan Laporan keuangan menggunakan mata uang rupiah.

Tabel 1. Prosedur Pemilihan Sampel

\begin{tabular}{|c|c|}
\hline Keterangan & $\begin{array}{c}\text { Jumlah } \\
\text { Obligasi }\end{array}$ \\
\hline Utang yang beredar per 15 Juni 2016 & 419 \\
\hline Utang bukan diterbitkan oleh perusahaan finance & $(167)$ \\
\hline Utang yang diterbitkan setelah 31 desember 2014 & $(107)$ \\
\hline Utang merupakan obligasi subordinasi & $(33)$ \\
\hline Utang yang berbentuk sukuk & $(2)$ \\
\hline Data tidak lengkap & $(11)$ \\
\hline Laporan keuangan dengan mata uang asing & $(3)$ \\
\hline Total obligasi yang digunakan sebagai sampel & 96 \\
\hline
\end{tabular}

Model yang digunakan dalam penelitian ini adalah model analisis regresi logit yang digunakan untuk menguji pengaruh antar variabel-variabel independen terhadap variabel dependen yang berupa variabel dummy. Adapun persamaan untuk menguji hipotesis secara keseluruhan dalam penelitian ini adalah sebagai berikut :

$$
\operatorname{Ln} \frac{A B}{1-A B}=\beta 0+\beta 1 \mathrm{M}+\beta 2 \mathrm{Cl}+\beta 3 \mathrm{Pr}+\beta 4 \mathrm{Q}+\varepsilon
$$

\section{Keterangan :}
Ln $\frac{A B}{1-A B}$ : Accounting based covenant yang diproksikan dengan variabel dummy, $1=$ jika kontrak utang menggunakan batasan-batasan akuntansi (accounting based covenant), $0=$ jika tidak.
$\beta_{0} \quad$ : konstanta
$\beta_{1-\beta 5} \quad$ : Koefisien regresi
$M \quad$ : jatuh tempo obligasi
$\mathrm{Cl} \quad$ : collateral (jaminan/agunan)
Pr : rasio profitabilitas
Q $\quad$ : kualitas obligasi
E : error term (kesalahan residual)

Accounting based covenant merupakan metode akuntansi yang didasarkan pada covenant yang telah disepakati bersama antara borrower dan lender (Scott, 2009). Dimana perusahaan sebagai borrower harus mentaati isi dari covenant tersebut untuk menjaga baik rasio keuangan ataupun hal lainnya sehingga perusahaan harus memilih metode akuntansi yang sesuai agar jangan sampai melanggar isi dari covenant tersebut. Covenant berusaha untuk menjaga kreditor dalam melawan segala bentuk perilaku oportunistik yang merupakan bagian dari debtholder seperti: claim delution, asset withdrawal, underinvestment dan asset substitution (Scott, 2009). Menurut Inamura (2009) ada tiga tipe covenant berbasis akuntansi (accounting based covenant). Pertama adalah ketentuan nilai kekayaan bersih (the net worth requirement provision), adalah covenant yang mensyaratkan issuer untuk mengelola nilai kekayaan bersih minimal yang telah ditetapkan. Kedua, ketentuan persyaratan pendapatan bersih (the net income requirement provision), adalah covenant yang membatasi issuer dalam mengelola pendapatan bersih minimum yang telah disepakati. Ketiga, Batasan dividen (the 
dividend restriction), adanya pembatasan bagi issuer dalam pembagian dividen yang ditetapkan dengan menggunakan angka akuntansi.

Accounting based covenant merupakan variabel dummy dengan cara: $1=$ jika kontrak utang menggunakan batasan-batasan akuntansi (accounting based covenant), $0=$ jika tidak. Jenis covenant bisa dilihat dari catatan atas laporan keuangan perusahaan pada tahun penerbitan obligasi, disana akan didapat batasan-batasan tentang penerbitan obligasi apakah membatasi angka-angka akuntansi ataukah jaminan.

Maturity merupakan tahun jatuh tempo obligasi dikurangi dengan tahun penerbitan (Inamura, 2009). Jatuh tempo (maturity) merupakan tanggal dimana pemegang obligasi akan mendapatkan pembayaran kembali pokok atau nilai nominal obligasi yang dimilikinya (www.idx.co.id). Periode jatuh tempo obligasi bervariasi mulai dari 365 hari sampai dengan diatas 5 tahun. Maturity diukur dengan periode tahun penerbitan obligasi sampai dengan waktu pelunasan pokok pinjaman. Jangka waktu obligasi bisa dilihat dari tahun jatuh tempo - tahun penerbitan obligasi, data tersebut bisa didapat dari situs BEI mengenai daftar penerbit obligasi.

Collateral yang dimaksud disini adalah asset collateral yaitu rasio total asset tetap terhadap total asset (Ojah and Pillay, 2009). Dalam penjanjian utang-piutang, jaminan atau agunan adalah aset pihak peminjam yang dijanjikan kepada pemberi pinjaman jika peminjam tidak dapat mengembalikan pinjaman tersebut. collateral diukur dengan aset tetap bersih dibagi dengan total aset. Rumus yang digunakan :

Collateral $=\underline{\text { Total aset tetap }}$

Total aset

Profitabilitas dapat diukur melalui jumlah laba operasi, laba bersih, tingkat pengembalian investasi/ aktiva, dan tingkat pengembalian ekuitas pemilik. Rasio profitabilitas atau rasio rentabilitas menunjukan keberhasilan perusahaan dalam menghasilkan keuntungan. Profitabilitas diukur salah satunya menggunakan rasio Return on Investment (ROI). profitabilitas diukur dengan laba bersih dibagi dengan total penjualan. Data mengenai laba bersih dan total penjualan bisa didapat dari laporan keuangan tahunan issuer 1 tahun sebelum penerbitan obligasi. Rumus yang digunakan:

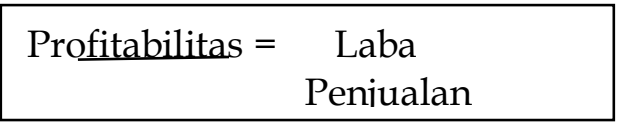

Peringkat obligasi adalah salah satu indikator penting mengenai kualitas kredit perusahaan (Rauh and Sufi, 2010). Rating Efek di Indonesia dilakukan oleh PT Pefindo (Pemeringkat Efek Indonesa) yang merupakan Badan Pemeringkat yang dibentuk oleh Bapepam. Peringkat terbaru berkisar antara AAA sampai dengan $\mathrm{D}$ sejumlah 18 peringkat, lebih lengkapnya terdiri dari: $\mathrm{AAA}, \mathrm{AA}+, \mathrm{AA}, \mathrm{AA}-\mathrm{A}+, \mathrm{A}, \mathrm{A}-, \mathrm{BBB}+, \mathrm{BBB}$, BBB-, BB+, BB, BB-, B+, B, B-, CCC, D (www.pefindo.com). Mariano dan Tribo (2009) menemukan bahwa perusahaan dengan kualitas yang baik berpengaruh pada pembentukan covenants. Quality (kualitas obligasi) diukur dengan menggunakan skala ordinal 1 sampai dengan 10 dari rating obligasi tertinggi AAA sampai dengan D untuk rating terakhir obligasi sebelum obligasi diterbitkan. Data mengenai rating obligasi tersebut diatas bisa didapat dari catatan atas laporan keuangan.

Pengujian keseluruhan model dilakukan dengan melihat nilai -2 Log Likelihood (2LL) semakin tinggi angka-angka dalam tabel semakin baik model yang diuji menunjukkan bahwa model yang dihipotesiskan fit dengan data. Hasil pengujian menunjukkan bahwa nilai -2LL sebesar 103,275, ini menunjukkan model regresi yang lebih baik atau dengan kata lain model yang dihipotesiskan telah memiliki kesesuaian dengan data. Besarnya nilai koefisien determinasi pada model regresi logistik 
ditunjukkan oleh nilai Negelkerke $R$ Square. Nilai Negelkerke $R$ Square dapat diintepretasikan seperti nilai $R$ Square pada regresi berganda.

\section{HASIL PENELITIAN DAN PEMBAHASAN}

Hasil pengujian dengan menggunakan Hosmer and Lemeshow's Test menunjukkan nilai Chi-square sebesar 11,856 dengan signifikansi sebesar 0,105. Berdasarkan hasil tersebut, karena nilai signifikansi untuk keseluruhan sampel lebih besar dari 0,05 maka model regresi disimpulkan mampu memprediksi nilai obsevasinya dan layak untuk digunakan dalam analisis selanjutnya.

Hasil koefisien determinasi sebesar 0,101. Hasil perhitungan besarnya nilai Negelkerke R Square untuk obligasi finance menunjukkan nilai sebesar 0,101 yang berarti variabilitas variabel dependen yang dapat dijelaskan oleh variabel independen adalah sebesar $10,1 \%$, sedangkan sisanya sebesar $89,9 \%$ dijelaskan oleh variable-variabel lain diluar model penelitian. Ternyata dengan mengurangi variabel independen dari 10 variabel yang diteliti Sulistiani et.al. (2014) menjadi 4 variabel yang signifikan saja, bisa menurunkan nilai koefisien determinasi yang cukup signifikan yaitu $40 \%$.

Penelitian ini memberikan kenyataan bahwa jumlah obligasi yang diterbitkan oleh perusahaan finance semakin meningkat dibandingkan 5 tahun sebelumnya. Penelitian Sulitiani, et.al. (2014) untuk periode 2005-2009 ada 81 obligasi yang diterbikan oleh perusahaan finance yang dijadikan sampel, sedangkan pada penelitian ini untuk periode 2010-2014 bertambah menjadi 96 obligasi. Hal tersebut mendukung teori Jensen and Meckling (1976) mengenai teori agensi bahwa penerbitan utang bisa mengurangi biaya pengawasan yang terjadi akibat adanya agensi dalam perusahaan. Penelitian ini juga memberikan kenyataan bahwa jumlah obligasi yang berbasis akuntansi makin berkurang dari tahun-ke tahun di Indonesia. Hal ini terbukti dengan jumlah obligasi yang berjenis accounting based covenant pada periode 2005-2009 sejumlah 33,33\% untuk perusahaan finance (Sulistiani, et.al, 2014), sedangkan pada periode tahun 2010-2014 menurun menjadi 26\% dari total obligasi yang beredar. Jumlah tersebut masih lebih banyak dibandingkan di Jepang yang hanya berjumlah 2,9\% dari total obligasi yang beredar (Innamura, 2009).

Hasil pengujian hipotesis dari variabel-variabel yang diteliti terhadap pembentukan covenant menunjukkan variabel dengan nilai $p$ lebih kecil dari $a=5 \%$ $(0,05)$ adalah variabel kualitas obligasi yaitu sebesar 0.037 . Hasil tersebut menunjukkan bahwa kualitas obligasi berpengaruh signifikan pada pembentukan covenant yang berbasis akuntansi sedangkan variabel yang lain tidak berpengaruh.

Tabel 2. Hasil Uji Regresi Logistik Obligasi

\begin{tabular}{ccccc}
\hline & B & S.E. & Wald & Sig. \\
\hline $\mathrm{Mt}$ & .059 & .138 & .182 & .670 \\
$\mathrm{Cl}$ & 15.924 & 11.081 & 2.065 & .151 \\
$\mathrm{Pr}$ & .055 & .140 & .156 & .692 \\
$\mathrm{Q}$ & -.262 & .125 & 4.353 & .037 \\
Constanta & -.881 & .745 & 1.398 & .237 \\
\hline
\end{tabular}

\section{Pengaruh Jangka Waktu Obligasi Terhadap Pembentukan Covenant}

Berdasarkan hasil pengujian pengaruh jangka waktu obligasi terhadap pembentukan covenant, penelitian ini tidak berhasil menemukan adanya pengaruh variabel maturity terhadap pembentukan covenant. Hasil tersebut mendukung Inamura (2009). Tapi tidak mendukung penelitian yang dilakukan oleh El Gazzar dan Pastena 
(1991), Mu, et.al. (2013), Chaudari, et.al. (2014), serta Sulistiani, et.al. (2014) yang menemukan pengaruh baik positif ataupun negatif. Hasil pengujian yang tidak berhasil menemukan adanya pengaruh signifikan positif pada obligasi perusahaan finance dari variabel jangka waktu obligasi menunjukkan bahwa jangka waktu obligasi perusahaan finance tidak dapat mempengaruhi perusahaan dalam mensyaratkan covenant yang berbasis akuntansi. Jangka waktu obligasi yang panjang cenderung membuat pemegang obligasi tidak ingin menggunakan perjanjian berbasis akuntansi pada kontrak utangnya (Inamuara, 2009). Pada periode pengamatan yang berbeda juga menghasilkan hasil yang berbeda pula meskipun sama-sama dilakukan di Indonesia tapi penelitian tidak bisa mendukung hasil penelitian Sulistiani et.al. (2014) yang menemukan pengaruh positif dari jangka waktu terhadap pembentukan covenant.

\section{Pengaruh Agunan/Jaminan Terhadap Pembentukan Covenant}

Berdasarkan hasil pengujian pengaruh jaminan terhadap pembentukan covenant, penelitian ini tidak berhasil menemukan adanya pengaruh positif variabel agunan/jaminan terhadap pembentukan covenant pada keseluruhan obligasi perusahaan finance. Hasil ini secara umum mendukung hasil Mansi and Wald (2012) yang tidak menemukan adanya pengaruh. Akan tetapi tidak mendukung penelitian Sulistiani, et.al. (2014). Hasil pengujian yang tidak berhasil menemukan adanya pengaruh positif dari variabel agunan/jaminan menunjukkan bahwa jaminan merupakan hal tidak cukup penting untuk dipertimbangkan dalam pembentukan covenant. Jaminan disini diproxykan dengan rasio asset collateral (total aset tetap dibagi dengan total aset). Jumlah proporsi aset tetap dalam keseluruhan total aset akan menunjukkan seberapa besar jumlah aset tetap terhadap total aset. Hal ini dimungkinkan karena pada periode pengamatan ini khususnya untuk obligasi yang diterbitkan oleh perusahaan finance lebih banyak covenant yang berbasis jaminan yang ini menindikasikan bahwa masyarakat pemegang obligasi lebih puas jika obligasi tersebut dijamin dengan aset tertentu dibandingkan hanya dibatasi dengan angkaangka akuntansi (Sulistiani, et. al. : 2014).

\section{Pengaruh Profitabilitas Terhadap Pembentukan Covenant}

Berdasarkan hasil pengujian pengaruh profitabilitas terhadap pembentukan covenant, penelitian ini tidak berhasil menemukan adanya pengaruh variabel profitabilitas terhadap pembentukan covenant pada obligasi perusahaan finance. Hasil ini secara umum mendukung hasil penelitian sebelumnya yang dilakukan oleh Cai, et.al. (2011) dan Inamura (2009) yang menemukan tidak ada pengaruh. Hasil penelitian ini tidak mendukung penelitian yang dilakukan oleh Chaudari, et.al. (2014) dan Mu, et.al. (2013). Hasil pengujian yang tidak berhasil menemukan adanya pengaruh signifikan dari variabel profitabilitas menunjukkan bahwa jika rasio profitabilitas tidak mempengaruhi pembentukan covenant akan didasarkan pada akuntansi (accounting based covenant). Hal tersebut menunjukkan bahwa debitur menganggap bahwa laba perusahaan tidak cukup untuk memberikan jaminan keamanan akan obligasi yang diterbitkan sehingga mereka tetap memilih untuk meminta jaminan tertentu atas obligasi yang diterbitkan.

\section{Pengaruh Kualitas Obligasi Terhadap Pembentukan Covenant}

Berdasarkan hasil pengujian pengaruh kualitas obligasi terhadap pembentukan covenant, penelitian ini berhasil menemukan adanya pengaruh positif variabel kualitas obligasi terhadap pembentukan covenant. Hasil ini secara umum tidak mendukung hasil penelitian sebelumnya yang dilakukan oleh Cai, et.al. (2011) dan Chaudari, et.al. 
(2014) yang menemukan tidak ada pengaruh serta penelitian Raisel (2014) yang menemukan pengaruh negatif. Akan tetapi penelitian ini mendukung hasil penelitian Rauh and Sufi (2010), dan Sulistiani, et. al. (2014). Hasil pengujian yang berhasil menemukan adanya pengaruh signifikan positif dari variabel kualitas obligasi menunjukkan bahwa rating obligasi yang tinggi akan mempengaruhi pembentukan covenant berbasis akuntansi. Ini berarti bahwa perusahaan yang menerbitkan obligasi dengan rating yang tinggi lebih dipercaya karena debitur tidak mementingkan jaminan untuk utang yang diterbitkan melainkan percaya akan angka-angka akuntansi yang ada dalam laporan keuangan issuer. Dapat disimpulkan bahwa kualitas obligasi sangat mempengaruhi suatu perusahaan untuk tidak perlu memberikan jaminan tertntu melainkan patuh pada angka-angka akuntansi yang ditetapkan dalam perjanjian utang pada perusahaan go publik, sehingga sangat penting bagi perusahaan untuk mempertahankan kualitas yaitu berupa rating obligasi yang mereka terbitkan.

\section{SIMPULAN}

Penelitian ini memberikan kenyataan bahwa jumlah obligasi yang diterbitkan oleh perusahaan finance semakin meningkat dibandingkan 5 tahun sebelumnya. Penelitian Sulitiani et.al. (2014) untuk periode 2005-2009 ada 81 obligasi yang diterbikan oleh perusahaan finance yang dijadikan sampel, sedangkan pada penelitian ini untuk periode 2010-2014 bertambah menjadi 96 obligasi. Hal tersebut mendukung teori Jensen and Meckling (1976) megenai teori agensi bahwa penerbitan utang bisa mengurangi biaya pengawasan yang terjadi akibat adanya agensi dalam perusahaan. Penelitian ini juga memberikan kenyataan bahwa jumlah obligasi yang berbasis akuntansi makin berkurang dari tahun-ke tahun di Indonesia. Hal ini terbukti dengan jumlah obligasi yang berjenis accounting based covenant pada periode 2005-2009 sejumlah 33,33\% untuk perusahaan finance (Sulistiani, et.al, 2014), sedangkan pada periode tahun 2010-2014 menurun menjadi 26\% dari total obligasi yang beredar.

Berdasarkan hasil penelitian ini dapat disimpulkan bahwa faktor-faktor yang menentukan pembentukan accounting based covenant salah satunya adalah kualitas obligasi. Peringkat obligasi adalah salah satu indikator penting mengenai kualitas kredit perusahaan oleh karenanya dijadikan salah satu bahan pertimbangan dalam penerbitan obligasi. Penelitian ini tidak bisa membuktikan adanya pengaruh jangka waktu obligasi, jaminan perusahaan, dan profitabilitas perusahaan. Hal tersebut memberikan bukti secara empiris bahwa rating obligasi yang menunjukkan kualitas obligasi yang diterbitkan perusahaan finance cukup mengindikasikan keamanan suatu obligasi dan dianggap lebih bisa menjamin kemampuan perusahaan dalam memenuhi kewajibannya, sehingga dijadikan dasar dalam keputusan pembentukan covenant dalam suatu kontrak utang publik. Sesuai dengan teori kontrak yang dikemukakan oleh Jensen \& Meckling (1976) bahwa ketika perusahaan mendekati pelanggaran kontrak, manajemen akan melakukan pengaturan laba dan hal itu juga bisa digunakan agar covenant dalam suatu kontrak utang yang mereka terbitkan tidak terlalu ketat. Penelitian ini bisa dijadikan dasar acuan dalam memilih variabel yang sesuai dalam pembentukan covenant khususnya di Indonesia

Hasil pengujian yang menemukan pengaruh pada variabel-variabel tersebut di atas konsisten dengan penelitian yang dilakukan oleh Sulistiani, et.al. (2014) yang juga menemukan pengaruh positif dari kualitas obligasi terhadap perjanjian utang berbasis akuntansi. Hasil penelitian ini menunjukkan ketidakkonsistenan hasil dari periode pengamatan yang berbeda dari obligasi yang diterbitkan oleh perusahaan finance di Indonesia. Dimana pada periode 2005-2009 ada 4 variabel yang mempengaruhi accounting based covenant yaitu: jangka waktu, jaminan, profitabilitas dan kualitas 
obligasi (Sulistiani, et.al., 2014), sedangkan pada periode penelitian kali ini yaitu 20102014 hanya variabel kualitas obligasi saja yang mempengaruhi pembentukan covenant berbasis akuntansi.

Penelitian mendatang bisa menggunakan alat analisis berupa E-Views dengan meneliti semua jenis obligasi baik yang konvensional maupun syariah (sukuk). Selain itu juga bisa dengan menambah variabel moderating ataupun intervening yang sesuai dalam penelitian obligasi di Indonesia.

\section{DAFTAR PUSTAKA}

Bhattacharyay, B.N. (2011), "Bond market development in Asia: an empirical analysis of major determinants", Journal of Asian Economics, Vol. 24 No. 1, pp. 124-137.

Booth, L., Cleary, S. and Purda, L. (2013), “Debt rating initiations: natural evolution or opportunistic behavior?", Journal of Modern Accounting and Auditing, Vol. 9 No. 12, pp. 1574-1595.

Cai, K., Jiang, X. and Lee, H. (2011), "Debt IPO waves, investor sentiment, market conditions, and issue quality", working paper, University of Michigan, MI.

Chaudhari, K., Raje, M. and Singh, C. (2014), "Corporate bond markets in India: a study and policy recommendations", Indian Institute of Management: Bangalore, Working Paper 450

El Gazzar, S. dan V. Patena. (1991). Factors effecting the scope and initial tighness of covenant restrictions in private lending agreements, Contemporary Accounting Research, 8(1), 132-151.

Inamura, Y. (2009). The determinants of accounting-based covenants in public debt contracts, Journal of international Business Research, 8(2), 1-15.

Jensen, M.C. dan W.H. Meckling.(1976). The theory of the firm : managerial behaviour, agency costs and ownership structure, Journal of Financial Economics, 3(4), 305-360.

Mansi, S., Qi, Y. and Wald, J. (2012), “Debt covenants and bankruptcy risk”, working paper, Virginia Tech, VA.

Mariano, B. dan J.A. Tribo. (2009). Debt covenant and corporate investment, University Carlos III of Madrid Working Paper Series.

Mu, Y., Phelps, P. and Stotsky, J. (2013), "Bond markets in Africa”, IMF Working Paper $\mathrm{WP} / 13 / 12$.

Ojah, K. and Pillay, K. (2009), "Debt markets and corporate debt structure in an emerging market: the South African example", Economic Modelling, Vol. 26 No. 1, pp. 1215-1227.

Rauh, J. and Sufi, A. (2010), "Capital structure and debt structure", Review of Financial Studies, Vol. 23 No. 12, pp. 4242-4280.

Reisel, N. (2014), "On the value of restrictive covenants: empirical investigation of public bond volumes", Journal of Corporate Finance, Vol. 27, pp. 251-268.

Scott, R. (2009). Financial accounting theory, London, Prentice Hall Inc.

Sulistiani, D. , Subroto, B. dan Chandrarin, G. (2014). Faktor-Faktor Yang Mempengaruhi Perjanjian Utang Berbasis Akuntansi (Accounting - Based Covenant) Pada Obligasi Yang Diterbitkan Oleh Perusahaan Yang Terdaftar Di Bursa Efek Indonesia. Proseedings SNA XVII di Mataram.

www.idx.co.id,

www.ojk.go.id 